\title{
Antenatal care service utilization and contributing factors: a community based study in rural Belgaum, Karnataka, India
}

\author{
Dillee Prasad Paudel ${ }^{1}$, Dr. B. R. Nilgar ${ }^{2}$, Dr. Manisha Bhandankar ${ }^{3}$ \\ ${ }^{I}$ M.Ed. MPH, Ph.D. Scholar, Department of Public Health, JN Medical College, KLE University, Nehru Nagar, \\ Belgaum, Karnataka, India \\ ${ }^{2}$ MBBS, MD. Professor, Department of Obstetrics and Gynecology, JN Medical College, KLE University, Nehru \\ Nagar, Belgaum, Karnataka, India \\ ${ }^{3}$ MD, Ph.D, Associate Professor, Department of Pediatrics , JN Medical College, KLE University, Nehru \\ Nagar, Belgaum, Karnataka, India
}

\begin{abstract}
:
Background: Pregnancy and childbirth are special events in women's lives and their families. Care of women during pregnancy is the most effective health interventions for safer and healthier outcome. Accessibility, quality of care, personal attitudes and socioeconomic characteristics affect on antenatal care (ANC) service use. This study was carried out to explore ANC service utilization pattern and contributing factors in a rural area of Belgaum in relation to generate Community based data of India for addressing the contributing factors.

Methods: Cross-sectional study was carried out from August 2012 to January 2013 in rural Belgaum Karnataka, India. All together 630 mothers with under one year child were interviewed by using pretested structure questionnaire after taking written consent. Analysis was done in computer based software; SPSS-20 version applying appropriate statistics.

Results: Out of 630 participants; $54.6 \%$ were $20-24$ years of age, $61.6 \%$ were having secondary education, $89.8 \%$ were house wives and $91.6 \%$ were Hindus. About $69.7 \%$ were from joint family with low economic status. Almost $94.8 \%$ were registered for ANC service, $85.7 \%$ visited $\geq 3$ times, $66.0 \%$ visited during first trimester and $42.3 \%$ visited in primary healthcare Centre. Three-fifth of the participants resided $\leq 6 \mathrm{Km}$. far from health service facilities. Education, family income, knowledge on ANC, distance of health facility from residence and transportation cost were significant contributors $(p<0.05)$ of ANC service utilization.

Conclusion: ANC service utilization rate in rural Belgaum is higher than the national level figure available till date. Education, income, knowledge level, distances and transportation cost were significant contributors. Effort to bring about to significant change in major factors at individual and community level supports to increase the full ANC service use.
\end{abstract}

Key words: Antenatal care, contributing factors, health service utilization, rural Belgaum

\section{Introduction}

Globally, estimated 1.5 billion women were of childbearing age (15 to 45 years old) in 2011. About 210 million become pregnant every year; of which $13.33 \%$ ( 28 million) belongs to developed countries and remaining huge portion $(86.66 \%)$ is from developing world including India.[1, 2] Pregnancy and childbirth are special events in women's lives, and, in fact, in the lives of their families.

Maternal and child healthcare (MCH) is a major component of primary health care (PHC).[3] After Alma-Ata declaration in 1978 and safe motherhood conference in 1987 in Nairobi, India focused on policies, plans and programs (PPP) related to mother and their child health care. First national health policy (1983), population policy (2000), revised health policy (2002) and National Rural Health Mission (NRHM) (2005) had focused on improvement of the health status of mother and their children in rural areas. The main objective of the mission was to reduce child and maternal mortality by providing universal access to equitable, affordable, accountable and effective primary health care services to women and children in rural areas. [4]

Utilization of health services is a complex phenomenon affected by multitude of factors including availability, distance, cost and quality of care as well as personal attitudes and socioeconomic conditions.[5] Care of women during pregnancy (after conception to Just before delivery) for safer and healthier pregnancy outcome is Antenatal Care (ANC). It is one of the most effective health intervention for preventing maternal morbidity and mortality. Antenatal period is an important opportunity for identifying pregnancy related threats to the mother and unborn baby's health. It supports to apply the possible preventive and curative measures to manage the complications in time by through various services viz. counseling on nutrition, birth preparedness, delivery care, post partum care and family planning options after delivery.[6] 
Regular and complete ANC consists some essential care service like least four times ANC checkup, immunization against tetanus, complete intake of iron and folic acid tablet, identification and management of risk at pregnancy and early referral of complication. [7] The study was carried out to explore the ANC service utility status and related contributing factors in the rural area of Belgaum for generating the data of India to address such factors.

\section{Materials And Methods}

This community based cross-sectional study was carried out during August 2012 to January 2013 in the rural area of Belgaum district, Karnataka, India. All together 630 mothers with a baby $(<1$ year old $)$ were selected as study participants. Statistical formula: $\mathrm{N}=\mathrm{Z}^{2} \mathrm{pq} / \mathrm{d}^{2}$ was used to calculate the number of participants considering 1.5 design effect, $10 \%$ non response rate and $5 \%$ tolerable error at the proportion of $40 \%$ full ANC service utilization prescribed by similar previous study. Two stages of 30 clustered sampling techniques were used. At first stage, Belgaum Taluk was selected from 10 Talukas of Belgaum district. There are 12 Primary Healthcare Centers (PHCs) in rural area of Belgaum Taluk. Five PHCs areas were selected randomly from these 12 PHCs as study site. For selecting villages, all sub-centre (SC) villages of each PHC and villages having no health institution (neither PHC nor SC) were listed separately. From each PHC area, the PHC village was selected. Further, two SC villages and three villages with no health institution from each SC area were selected randomly. Thus, the study covered thirty villages as clusters. In second stage, three random points were identified in each selected cluster to cover all areas of the village. Then, 21 participants ( 7 from each point of each village) were selected from each cluster. Data were collected by interview using pre-tested structured questionnaire. Voluntary informed consent was detailed before starting the study. Aaccuracy and reliability of data was mantained by checking and rechecking of its completness and correcting the errors before entrying into computer based software' Statistical Package for Social Sciences' (SPSS -20 versions). Percentage, mean, standard deviation and proportion was calculated as univariate analysis and chi-square $\left(\chi^{2}\right)$ tests, Odds ratio with logistic regression model were applied as bivariate and multivariate analysis. The criterion for statistical significance was set at the value of $\mathrm{p}<0.05$.

\subsection{Demographic finding of the study}

\section{Results}

Total 630 mothers (mean age \pm SD: $24.14 \pm 3.21$ years) participated in the study. About $54.6 \%$ of the participants were $20-24$ years of age whereas $37.1 \%$ were $25-29$ years. More than three-fifth $(61.6 \%)$ of the participants had at least secondary level of education followed by primary level $(18.7 \%)$ and PUC $(9.4 \%)$.

Least of the participants $(4.3 \%)$ had university degree. Almost $89.8 \%$ of the participants were house wife and most of them (91.6\%) were Hindus followed by 7.5\% Muslim. More than three-quarter (78.3\%) reported non-consanguineous marriage. Large portion of the participants $(69.7 \%)$ were from joint family with low ( $<3000 \mathrm{Rs} / \mathrm{month})$ economic status. Nearly half $(49.8 \%)$ of the participants' husband had secondary level education. About $45.6 \%$ of the participant's husbands were labors and negligible unemployed, (Table-1).

Table 1: Selected Socio Demographic characteristics of respondent $(N=630)$

\begin{tabular}{|c|c|c|}
\hline Characteristics & Frequency & Percentage \\
\hline Age of the respondent ( in year) & 12 & 1.9 \\
$\leq 19$ & 344 & 37.6 \\
$20-24$ & 234 & 5.1 \\
$25-29$ & 32 & 1.3 \\
$30-34$ & 8 & \\
$\geq 35$ & & 6.3 \\
(Mean age \pm SD: $24.14 \pm 3.21$ years) & & 18.4 \\
Educational status of respondent & 40 & 61.6 \\
Illiterate & 116 & 9.4 \\
Primary level & 388 & 4.3 \\
Secondary level & 59 & \\
PUC* & 27 & \\
University degree & & \\
\hline House wife & 566 & 3.7 \\
Farming & 23 & 1.3 \\
Government service & 8 & 0.8 \\
Private service & 5 & 0.6 \\
Lasiness & 4 & 3.5 \\
Other & 22 & 0.3 \\
\hline
\end{tabular}


Antenatal Care service utilization and contributing factors: a community based study in rural

\begin{tabular}{|c|c|c|}
\hline $\begin{array}{ll}\text { Religion } & \\
& \text { Hindu } \\
& \text { Muslim } \\
& \text { Jain } \\
& \text { Christian } \\
\end{array}$ & $\begin{array}{l}577 \\
47 \\
3 \\
3\end{array}$ & $\begin{array}{l}91.6 \\
7.5 \\
0.5 \\
0.5\end{array}$ \\
\hline $\begin{array}{l}\text { Marital relation } \\
\text { Consanguineous } \\
\text { Non- consanguineous }\end{array}$ & $\begin{array}{l}137 \\
493\end{array}$ & $\begin{array}{l}21.7 \\
78.3\end{array}$ \\
\hline $\begin{array}{c}\text { Family type } \\
\text { Nuclear } \\
\text { Joint } \\
\end{array}$ & $\begin{array}{r}191 \\
439 \\
\end{array}$ & $\begin{array}{r}30.3 \\
69.7 \\
\end{array}$ \\
\hline $\begin{array}{c}\text { Per-capita income per month in family }(\text { IRs**) } \\
<3000 \\
3000-10000 \\
>10,000\end{array}$ & $\begin{array}{l}127 \\
412 \\
91\end{array}$ & $\begin{array}{l}20.2 \\
65.4 \\
4.4\end{array}$ \\
\hline $\begin{array}{l}\text { Educational status of the husband } \\
\text { Illiterate } \\
\text { Primary level } \\
\text { Secondary level } \\
\text { PUC } \\
\text { University degree }\end{array}$ & $\begin{array}{l}56 \\
139 \\
314 \\
74 \\
47 \\
\end{array}$ & $\begin{array}{l}8.9 \\
22.1 \\
49.8 \\
11.7 \\
7.5\end{array}$ \\
\hline $\begin{array}{l}\text { Occupation of the Husband } \\
\text { Unemployed } \\
\text { Farming } \\
\text { Government service } \\
\text { Private service } \\
\text { Business } \\
\text { Labor } \\
\text { Other }\end{array}$ & $\begin{array}{l}3 \\
88 \\
37 \\
110 \\
90 \\
287 \\
15\end{array}$ & $\begin{array}{l}0.5 \\
14.0 \\
5.9 \\
17.5 \\
14.3 \\
45.6 \\
2.4\end{array}$ \\
\hline
\end{tabular}

SD: standard deviation, ${ }^{*}$ Pre university Course, ${ }^{* *}$ Indian rupees

\subsection{Obstetric history of the study participants}

More than half (50.2\%) of the participants had got marriage during the age of 20-24 years followed by $46.7 \%$ during adolescent ( $\leq 19$ years). About $25 \%$ were pregnant during the risky age ( $\leq 19$ years and $>30$ years) where as three-quarter had pregnant during 20-29 years of age. About $39.8 \%$ were of second parity followed by $7.5 \%$ first, $16.2 \%$ third and $6.5 \%$ forth and more. About $40.5 \%$ delivered only one child, $41.1 \%$ two and $18.4 \%$ three and more children. Nearly one out of every ten participants faced the problem of abortion during previous pregnancies. About $2.5 \%$ mothers gave still birth and $4.1 \%$ lost a baby during neonatal period; (Table- 2 ).

Table 2: Selected obstetric characteristics of the respondent $(n=630)$

\begin{tabular}{|c|c|c|}
\hline Characteristics & Frequency & Percentage \\
\hline $\begin{array}{c}\text { Age at marriage } \\
\leq 19 \text { years } \\
20-24 \text { years } \\
\geq 25 \text { years } \\
\end{array}$ & $\begin{array}{l}294 \\
316 \\
20\end{array}$ & $\begin{array}{l}46.7 \\
50.2 \\
3.1 \\
\end{array}$ \\
\hline $\begin{array}{c}\text { Age at first pregnancy } \\
\leq 19 \text { years } \\
20-24 \text { years } \\
25-29 \text { years } \\
\geq 30 \text { years }\end{array}$ & $\begin{array}{l}154 \\
435 \\
38 \\
3\end{array}$ & $\begin{array}{c}24.5 \\
69.0 \\
6.0 \\
0.5 \\
\end{array}$ \\
\hline $\begin{array}{l}\text { No of pregnancy (gravidity) } \\
\text { First } \\
\text { Second } \\
\text { Third } \\
\text { Forth and more }\end{array}$ & $\begin{array}{l}236 \\
251 \\
102 \\
41\end{array}$ & $\begin{array}{c}37.5 \\
39.8 \\
16.2 \\
6.5\end{array}$ \\
\hline $\begin{array}{l}\text { No of children delivered (parity) } \\
\text { First } \\
\text { Second } \\
\text { Third } \\
\text { Forth and more }\end{array}$ & $\begin{array}{l}255 \\
259 \\
87 \\
29\end{array}$ & $\begin{array}{c}40.5 \\
41.1 \\
13.8 \\
4.6\end{array}$ \\
\hline $\begin{array}{c}\text { History of Abortion in the life time } \\
\text { Yes } \\
\text { No }\end{array}$ & $\begin{array}{l}57 \\
573\end{array}$ & $\begin{array}{c}9.0 \\
91.0 \\
\end{array}$ \\
\hline $\begin{array}{c}\text { History of previous still births: } \\
\text { None } \\
\text { One }\end{array}$ & $\begin{array}{l}614 \\
16 \\
\end{array}$ & $\begin{array}{r}97.5 \\
2.5 \\
\end{array}$ \\
\hline $\begin{array}{c}\text { History of previous neonatal deaths: } \\
\text { Yes } \\
\text { No }\end{array}$ & $\begin{array}{l}26 \\
604\end{array}$ & $\begin{array}{c}4.1 \\
95.9\end{array}$ \\
\hline
\end{tabular}




\subsection{ANC service utilization pattern}

All most all 597 (94.2\%) of the participants were registered for any form of the antenatal health care service utilization during their last pregnancy period. ANC visit, TT immunization and iron and folic acid tablet consumption were the measures of health services utilization. About $87.9 \%$ of the registered women visited health institution for $\geq 3$ times whereas $14.3 \%$ had visited 1-2 times. About two-third (67.7\%) of the participants visited during their first trimester of pregnancy meanwhile $32.2 \%$ visited in second and $1.8 \%$ in third trimester. About $42.0 \%$ of the participants visited to the PHC for ANC service whereas $26.8 \%$ to civil hospital and $24.8 \%$ to private hospitals and nursing homes. Visit to health workers/ANMs and a local practitioner were found to be very rare $(4.4 \%$ and $2.0 \%$ respectively). About $66.5 \%$ mothers consumed the complete dose of iron and folic acid tablet $(\geq 100)$ regularly during their last pregnancy period whereas $69.8 \%$ took the complete dose of TT injection (at least 2 dose) followed by booster dose (16.6\%) and $13.8 \%$ of one dose. Most of the participants (94.8\%) used the laboratory investigation service for routine examination during their pregnancy where as only $18.6 \%$ consumed the calcium and vitamin during last pregnancy; (Table: 3 ).

Table 3: Health service utilization pattern during pregnancy

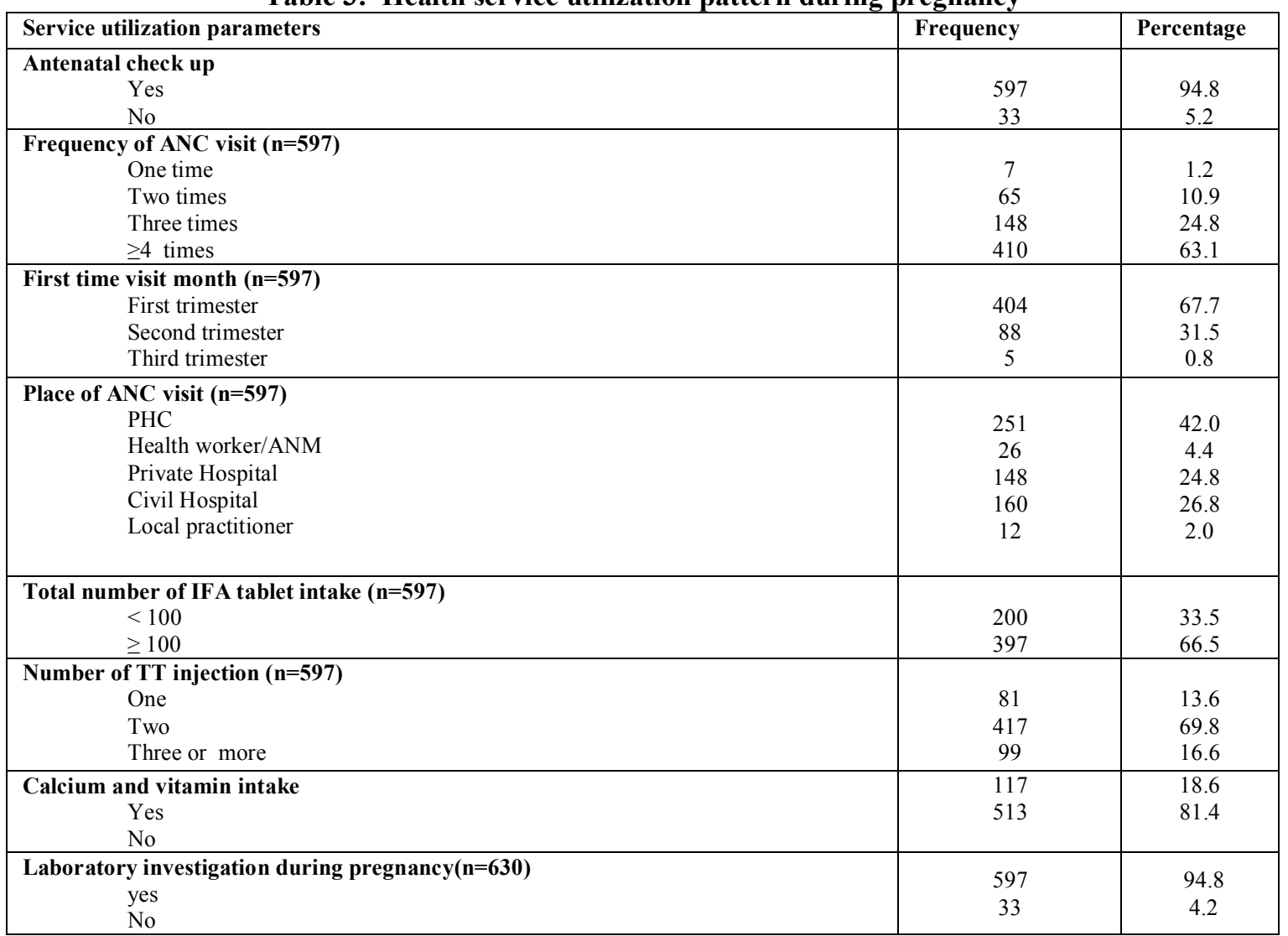

\subsection{Accessibility of the ANC service}

Table- 4 showed that $54.0 \%$ of the respondent resided $\leq 6 \mathrm{Km}$ from the nearest ANC service center while less than half $(46 \%)$ had complained the distance of health facility was in-covenant. More than $2 / 3^{\text {rd }}$ of the participants had paid $<40$ rupees for transportation at each visit whereas about one-third paid expensive cost ( $>40 \mathrm{Rs)}$ ) for the same service. About three-fifth $(60.6 \%)$ used the public bus as mode of transportation to visit the service centre, whereas $12.7 \%$ used private vehicle, $9.7 \%$ used own vehicle and $17 \%$ visited by foot. Nearly three- quarter of the foot users used to go in service center having the timing distance of $<1 / 2$ an hour, whereas $64.6 \%$ of the service users who used vehicle as mode of transportation used to go in the service centers of distance $\geq 1 / 2$ an hour. 
Antenatal Care service utilization and contributing factors: a community based study in rural

\begin{tabular}{|} 
Table 4: Accessibility of ANC services \\
\begin{tabular}{|c|l|l|}
\hline Characteristics & Frequency & Percentage \\
\hline Distance of health facility & 340 & \\
$\leq 6 \mathrm{Km}$ & 290 & 54.0 \\
$>6 \mathrm{Km}$ & & 46.0 \\
\hline Cost of transportation & 420 & \\
$\leq 40$ (Inexpensive) & 210 & 66.7 \\
$>40$ (Expensive) & 107 & 33.3 \\
\hline Mode of transportation & 382 & 17.0 \\
By foot & 80 & 60.6 \\
Public bus & 61 & 12.7 \\
Private vehicle & & 9.7 \\
Own vehicle & 82 & \\
By foot $(n=110)$ & 28 & 74.5 \\
$<1 / 2$ an hour & & 25.5 \\
$\geq 1 / 2$ an hour & 184 & \\
By vehicle $n=523)$ & 336 & 35.6 \\
$<1 / 2$ an hour & & 64.6 \\
$\geq 1 / 2$ an hour & & \\
\hline
\end{tabular}
\end{tabular}

\subsection{Factors associated with the ANC service use}

ANC service utilization is determined by several factors including socio-demographic characteristics, obstetrics history of the mother and accessibility of the health facilities and so on. Age of the mother, education, family income, types of family, occupation of the husband, education of husband, knowledge on antenatal care, distance of health facility from the residence and cost of transportation at each visit were found to be significant contributors $(p<0.05)$ of ANC service utilization in this study ( Table: 5).

It was also confirmed that the level of education of the mother and knowledge of mother on ANC were most important contributing factors $(\mathrm{p}<0.001)$ for ANC utilization. Educated women were 6.05 times $(95 \% \mathrm{CI}$ : 2.517-14.534) more likely to receive ANC service than those who had no education, and women who were highly knowledgeable were 18.40 times $(95 \%$ CI: 8.609-39.342) more likely to do so than those who were deficient in knowledge. Moreover, per-capita income per-month in the family and husband's education proved to be other most significant $(\mathrm{p}<0.001)$ contributing factors of ANC service utilization. Women who had high family monthly income were 3.61 times $(95 \%$ CI: $1.765-7.379)$ more likely $(\mathrm{p}=0.001)$ to have obtained ANC service than women with low-income. Similarly women whose husband were educated were 2.3 times $(95 \% \mathrm{CI}$ : 5.208-11.602) more likely to use the service than those who had no education.

It is interesting to note that the study also showed the women who felt the service was not burdensome were 3.37 times ( $95 \%$ CI: $1.643-6.925)$ more likely to use the service than the women who paid high cost as transportation $(\mathrm{p}<0.001)$. Similarly the women who lived nearby $(\leq 6 \mathrm{~km})$ were 3.91 times $(95 \%$ CI: $1.738-8.82)$ more likely to use the service than the women who lived far way $(\mathrm{p}<0.001)$. In addition the study also revealed that the women of age $20-35$ years were 4.6times $(95 \% \mathrm{CI}$ : $1.13-15.27)$ more likely $(\mathrm{p}=0.02)$ to use the service than the other age groups $(\leq 19$ and $>35)$. Type of the family and occupation of the husband also played an important role for utilizing the ANC service. The study revealed that the women who were from joint family were 2.27 times (95\% CI: 1.121-4.594) more likely $(\mathrm{p}=0.02)$ to use the service than the women from nuclear family. The women whose husband do the service/business were 2.84 times (95\%CI: 1.155-6.984) more likely $(\mathrm{p}=0.018)$ to use the ANC service than the women whose husband were farmers and labors; (Table:5).

Table 5: Association of antenatal service use and contributing factors by Binary logistic regression

\begin{tabular}{|c|c|c|c|c|c|c|}
\hline \multicolumn{2}{|c|}{ Variables } & \multicolumn{2}{|c|}{ ANC service use } & \multirow[t]{2}{*}{$\mathbf{O R}^{\mathrm{a}}$} & \multirow[t]{2}{*}{$95 \% \mathrm{CI}^{\mathrm{b}}$} & \multirow[t]{2}{*}{ P value } \\
\hline & & Yes $(n=597)$ & No(n=33) & & & \\
\hline \multirow[t]{2}{*}{ Age (in years) } & $20-35$ & $583(95.1)$ & $30(4.9)$ & \multirow[b]{2}{*}{4.61} & \multirow[b]{2}{*}{$1.13-15.27$} & \multirow[b]{2}{*}{$0.02 *$} \\
\hline & $\leq 19$ and $>35$ & $14(82.4)$ & $3(17.6)$ & & & \\
\hline \multirow[t]{2}{*}{ Educational level } & Some schooling & $567(95.8)$ & $25(4.20$ & \multirow[b]{2}{*}{6.05} & \multirow[b]{2}{*}{$2.517-14.534$} & \multirow[b]{2}{*}{$0.001 * * *$} \\
\hline & No schooling & $30(78.9)$ & $8(21.1)$ & & & \\
\hline \multirow[t]{2}{*}{ Religion } & Hindus & $36(95.8)$ & $16(4.2)$ & \multirow[b]{2}{*}{1.62} & \multirow[b]{2}{*}{$0.805-3.280$} & \multirow[b]{2}{*}{0.172} \\
\hline & Others & $236(93.3)$ & 1796.7) & & & \\
\hline \multirow[t]{2}{*}{ Occupation of mother } & Housewife & $535(94.5)$ & $31(5.5)$ & \multirow[b]{2}{*}{0.58} & \multirow[b]{2}{*}{$0.13-2.38$} & \multirow[b]{2}{*}{0.423} \\
\hline & Others & $62(96.9)$ & $2(3.1)$ & & & \\
\hline \multirow{2}{*}{$\begin{array}{l}\text { Monthly family } \\
\text { income (in IRs s }{ }^{c} \text { ) }\end{array}$} & $\geq 3000$ & $485(96.4)$ & $18(3.6)$ & \multirow[b]{2}{*}{3.61} & \multirow[b]{2}{*}{$1.765-7.379$} & \multirow[b]{2}{*}{$0.001 * * *$} \\
\hline & $<3000$ & $112(88.2)$ & $15(11.8)$ & & & \\
\hline \multirow[t]{2}{*}{ Types of family } & Joint & $422(96.1)$ & $17(3.9)$ & \multirow[b]{2}{*}{2.27} & \multirow[b]{2}{*}{$1.121-4.594$} & \multirow[b]{2}{*}{$0.02 *$} \\
\hline & Nuclear & $175(91.6)$ & $16(8.4)$ & & & \\
\hline \multirow[t]{2}{*}{ Family size } & Large & $549(94.8)$ & $30(5.2)$ & \multirow[b]{2}{*}{1.15} & \multirow[b]{2}{*}{$0.337-3.885$} & \multirow[b]{2}{*}{0.829} \\
\hline & Small & $48(94.1)$ & $3(5.9)$ & & & \\
\hline Occupation of & Service/ business & $231(97.5)$ & $6(2.5)$ & 2.84 & $1.155-6.984$ & $0.018 * *$ \\
\hline
\end{tabular}


Antenatal Care service utilization and contributing factors: a community based study in rural

\begin{tabular}{|c|c|c|c|c|c|c|}
\hline husband & Others & $366(93.1)$ & $27(6.9)$ & & & \\
\hline \multirow[t]{2}{*}{ Education of husband } & Some schooling & $551(96.0)$ & $23(4.0)$ & \multirow[b]{2}{*}{2.13} & \multirow[b]{2}{*}{$5.208-11.602$} & \multirow[b]{2}{*}{$0.001 * * *$} \\
\hline & No schooling & $46(82.1)$ & $10(17.9)$ & & & \\
\hline \multirow[t]{2}{*}{ Level of knowledge } & High & $556(97.5)$ & $14(2.5)$ & \multirow[b]{2}{*}{18.40} & \multirow[b]{2}{*}{$8.609-39.342$} & \multirow[b]{2}{*}{$0.001 * * *$} \\
\hline & Low & $41(68.3)$ & $19(3.7)$ & & & \\
\hline \multirow[t]{2}{*}{ Distance (in Km) } & $\leq 6 \mathrm{Km}^{\mathrm{d}}$ & $332(97.6)$ & $8(2.4)$ & \multirow[b]{2}{*}{3.91} & \multirow[b]{2}{*}{$1.738-8.821$} & \multirow[b]{2}{*}{$0.001 * * *$} \\
\hline & $>6 \mathrm{Km}$ & $265(9.4)$ & $25(8.6)$ & & & \\
\hline \multirow{2}{*}{$\begin{array}{l}\text { Mode of } \\
\text { transportation }\end{array}$} & By vehicle & $490(94.2)$ & $30(5.8)$ & \multirow[b]{2}{*}{0.49} & \multirow[b]{2}{*}{$0.137-1.528$} & \multirow[b]{2}{*}{0.193} \\
\hline & By foot & $107(97.3)$ & $3(2.7)$ & & & \\
\hline \multirow{3}{*}{$\begin{array}{l}\text { Cost of transportation } \\
\text { (IRs) }\end{array}$} & $\leq 40$ (Inexpensive) & $410(96.9)$ & $13(3.1)$ & \multirow[b]{3}{*}{3.37} & \multirow[b]{3}{*}{$1.643-6.925$} & \multirow[b]{3}{*}{$0.001 * * *$} \\
\hline & $>40$ (Expensive) & $187(90.3)$ & $20(9.7)$ & & & \\
\hline & $\leq 19$ and $>30$ & $146(93.0)$ & $11(7.0)$ & & & \\
\hline \multirow[t]{2}{*}{ Gravidity } & $\geq 2$ & $374(94.9)$ & $20(5.1)$ & \multirow[b]{2}{*}{1.09} & \multirow[b]{2}{*}{$0.532-2.234$} & \multirow[b]{2}{*}{0.814} \\
\hline & First & $223(94.5)$ & $13(5.5)$ & & & \\
\hline \multirow[t]{2}{*}{ Parity } & $\geq 2$ (multi parity) & $355(94.7)$ & $20(5.3)$ & \multirow[b]{2}{*}{0.95} & \multirow[b]{2}{*}{$0.465-1.953$} & \multirow[b]{2}{*}{0.896} \\
\hline & First & $242(94.9)$ & $13(5.1)$ & & & \\
\hline \multirow[t]{2}{*}{ History of Abortion } & Yes & $54(98.2)$ & $1(1.8)$ & \multirow[b]{2}{*}{3.19} & \multirow[b]{2}{*}{$0.426-23.748$} & \multirow[b]{2}{*}{0.233} \\
\hline & No & $543(94.4)$ & $32(5.6)$ & & & \\
\hline \multirow[t]{2}{*}{ History of still births } & Yes & $16(100.0)$ & $0(0.0)$ & \multirow[b]{2}{*}{1.05} & \multirow[b]{2}{*}{$1.037-1.077$} & \\
\hline & No & 581(94.6) & $33(5.4)$ & & & 0.341 \\
\hline History of neonatal & Yes & $25(96.2)$ & $1(3.8)$ & & & \\
\hline deaths & No & $572(94.7)$ & $32(5.3)$ & 1.39 & $0.184-10.65$ & 0.745 \\
\hline
\end{tabular}

Figures in brackets show the percentage value of each finding

${ }^{a}$ OR: Odds Ratio, ${ }^{b} \mathrm{CI}$ : Confidence Interval, ${ }^{c} \mathrm{Km}$ : Kilo meter, ${ }^{d}$ IRs: Indian Rupees,

* Significant at $(p<0.05),{ }^{* *}$ Significant at $(p<0.01), * * *$ Significant at $(p<0.001)$

\section{Discussion}

According to WHO, every pregnant woman should receive at least four ANC visit to the health institution during pregnancy.[8] In this study, about 94.8 percent of the participants had used at least any form of ANC service which is more than the state report of Karnataka in 2009.[9] Utilization of individual ANC services like registration in first trimester (67.7\%), at least two dose of TT injection (69.8\%), at least four ANC checkup $(63.1 \%)$ and adequate iron and folic acid tablet intake $(66.5 \%)$ was similar to the study conducted in Tribal area of Maharashtra[10] and fewer than the study in Kerala India.[11]

Place of visit for ANC service in this study was found as $42.3 \%$ to PHC followed by $26.3 \%$ to civil hospital and $24.7 \%$ to private hospital which was slightly differ with the report of other health surveys (Reproductive and Child Health, District Level Household Survey and Facility Survey) under Reproductive and Child Health Project conducted at different time in India. These surveys reported that, $31.3 \%$ used to take the service in their own home where as 30.2\% from Government hospitals, 9.6\% from PHC and 5.6\% from sub centre and rest of others took from private health facilities.[12]

With regard to the contributing factors of ANC service utilization; this study revealed that ANC service utilization is significantly influenced by maternal age, education of mother and her husband Education is very meaningful to influence the mother for health service utilization. Subject's education and husband's education of the some schooling supported to increase the ANC service utilization 6.5 times and 2.13 times respectively in this study which is in line with the reports of other studies carried out in India and abroad.[10,13,14]. Higher use of ANC service by educated groups could be due to the 'higher the educational status, better the understanding of information and better the knowledge about importance of the services'.

Per- capita income per- month in family of Rs.3000 and above increased the likelihood of ANC utilization by 3.61 times which was consistent with the other study reports. $[10,13]$ This could be because of the fact that the better income increases the ability to pay for the transportation, health care and other costs. Knowledge of the mother was the strong contribution factor of ANC utilization. Having high level knowledge about ANC in our study supported to increase utilization by eighteen times which was consistence with the report from India, Ethiopia, Japan and Indonesia.[13-15] Good knowledge of mothers support them to know the benefit of ANC for their own health and unborn babies' health and willing to use the services timely.

The result of this study showed that mothers whose husbands were service holders or business person were more likely to use ANC service which was matched with the study result from Jakarta, Indonesia. [14] The office workers and business persons have good monthly income then the farmers and labors which might affect to regular use of ANC services of wives.

Accessibility of health services is another significant contributing factor for ANC service utilization. This study revealed that the mother who lived nearer from health facility utilized more ANC service compared to those who lived far which is in line with the other study findings. [14-15]. The finding was as per our expectation that short distance should contribute to regular and more ANC services because they can come easily in minimum traveling cost and time. The study also showed that the inexpensive cost of transportation is 
highly significant with the more ANC service utilization. People who live in rural community have no regular source of income and want to perch the service in minimum expenditure which supports to increase the rate of ANC service utilization.

However, this study revealed that some socio demographic factors (such as religion, occupation of mother, family size etc) and past obstetrics history of mothers (such as parity, gravidity, previous neonatal death, still birth and low birth weight etc) were not significantly associated with the utilization of the ANC services in the rural area of Belgaum, Karnataka India.

\section{Conclusion}

This study revealed that ANC service utilization rate in rural Belgaum is higher than the national and state level figure available to date. However it is worth noting that large number of mothers who attended ANC did not receive enough of visits and initiate the visit later for full ANC service utilization as recommended by WHO and the safe motherhood program of India. Furthermore age of mother, maternal and husband education, level of knowledge of mother on ANC service and its benefit, cost of transportation and the distance of service centers from residence were major contributing factors for ANC services use. Hence effort to bring about to significant change in those major contributing factors at individual and community level by public awareness and behavioral change communication will support to encourage to full ANC service utilization.

\section{Acknowledgement}

The study team wants to put the sincere gratitude to the KLE University for creating favorable environment and initiating to conduct the research in rural area of Belgaum. The authors are thankful to ICDS office Belgaum, UGC Nepal, PHC staffs, ANMs, Aaganwadi workers, and study participants for their valuable support during the study for bringing it in logical end.

\section{References}

[1]. Worldwide statistics 2011.[Available from http://www.google.com] (cited on 26-03-2012)

[2]. UNFPA. The State of the World's Midwifery: Delivering Health, Saving Lives, 2011.

[3]. World Health Organization (WHO). Health for all. Series No. 1. WHO, Geneva: 1978.

[4]. Kumar S. Challenges of maternal mortality reduction and opportunities under national rural health mission - a critical appraisal. Indian Journal of Public Health 2005; 49(3): 163-167.

[5]. Antenatal care in developing countries: Promises, achievements and missed opportunities. An analysis of trends, levels and differentials, 1990-2001. WHO Geneva, Switzerland 2003.

[6]. WHO. What is the effectiveness of antenatal care? (Supplement). Copenhagen. 2005.

[7]. End Decade Database, UNICEF 2001. Available at [http://www.childinfo.org/eddb/maternal/index.htm] (Cited on 27 December 2011)

[8]. World health organization (WHO). Antenatal care in developing countries: promises, achievements and missed opportunities: an analysis of trends, levels and differentials, 1990-2001. WHO Library cataloguing in publication 2003.

[9]. Bihar fact sheet: Coverage evaluation survey 2009.

[10]. Mumbare SS, Rage R. Antenatal care service utilization, delivery practice and factors affecting them in Tribal area of North Magharashtra. Indian journal of community medicine 2011; 36(4): 287-90

[11]. Sumitra S. Aswathy A and et al. Maternal and child health utilization in married women of age 15-45 years. Journal of communicable Disease 2006; 38(1): 102-5.

[12]. Shaikh Tayyaba KRA, Dr. Khairkar VP. Utilization of Maternal and Child Health Care Services among Muslims in India on the basis of report of RCH-2002, District level household survey (DLHS-2) 2002-2004 and Facility Survey under Reproductive and Child Health Project 2002-2003.

[13]. Gurmesa T. Antenatal care service utilization and associated factors in Metekel zone Northwest, Ethiophia. Ethipo journal of Health science 2009; 19(2): 111-18.

[14]. Effendi R, Isaranurug S, Chompikul J. Factors related to regular utilization of antenatal care service among the post partum mothers in Pasar Rebo general Hospital, Jakarta, Indonesia. Journal of Public Health and development 2008; 6(1):113-22.

[15]. Yang Y, YoshitokuY, MD. Rashid Harun OR, Junichi S. Factors affecting the utilization of antenatal care service among women in Kham District, Xiengkhouang Proviance, Lao PDR. Nayoga journal of Medical science 2010; 72: 23 -33. 